\title{
Impact of erythromycin on a non-target organism: Cellular effects on the freshwater microalga Pseudokirchneriella subcapitata
}

\author{
Manuela D. Machado ${ }^{\mathrm{a}, \mathrm{b}, *}$, Eduardo V. Soares ${ }^{\mathrm{a}, \mathrm{b}, *}$ \\ ${ }^{a}$ Bioengineering Laboratory-CIETI, ISEP-School of Engineering, Polytechnic Institute of Porto, Rua Dr António Bernardino de Almeida, 431, 4249-015 Porto, Portugal \\ ${ }^{\mathrm{b}}$ CEB-Centre of Biological Engineering, University of Minho, Campus de Gualtar, 4710-057 Braga, Portugal
}

\section{A R T I C L E I N F O}

\section{Keywords:}

Cell membrane integrity (viability)

Erythromycin

Metabolic activity

Mitochondrial function

Photosynthesis

Toxicity

\begin{abstract}
A B S T R A C T
The increasing and indiscriminate use of antibiotics is the origin of their introduction in aquatic systems through domestic and livestock effluents. The occurrence of erythromycin (ERY), a macrolide antibiotic, in water bodies raises serious concerns about its potential toxic effect in aquatic biota (non-target organisms), particularly in microalgae, the first organisms in contact with aquatic contaminants. This study aimed to evaluate the possible toxic effects of ERY on relevant cell targets of the freshwater microalga Pseudokirchneriella subcapitata. Algal cells incubated with significant environmental ERY concentrations presented disturbance of the photosynthetic apparatus (increased algal autofluorescence and reduction of chlorophyll $a$ content) and mitochondrial function (hyperpolarization of mitochondrial membrane). These perturbations can apparently be attributed to the similarity of the translational machinery of these organelles (chloroplasts and mitochondria) with the prokaryotic cells. $P$. subcapitata cells treated with ERY showed a modification of metabolic activity (increased esterase activity) and redox state (alteration of intracellular levels of reactive oxygen species and reduced glutathione content) and an increased biovolume. ERY induced an algistatic effect: reduction of growth rate without loss of cell viability (plasma membrane integrity). The present study shows that chronic exposure $(72 \mathrm{~h})$, at low ( $\mu \mathrm{g}$ $\mathrm{L}^{-1}$ ) ERY concentrations (within the range of concentrations detected in surface and ground waters), induce disturbances in the physiological state of the alga $P$. subcapitata. Additionally, this work alerts to the possible negative impact of the uncontrolled use of ERY on the aquatic systems.
\end{abstract}

\section{Introduction}

Erythromycin (ERY) is a broad-spectrum macrolide antibiotic (ATB). It binds reversibly to the 23S rRNA molecule in the 50S subunit of the ribosome, inhibiting translocation of peptidyl tRNA, and thereby inhibiting protein synthesis in bacteria (Davies and Davies, 2010). ERY is effective against a wide variety of bacteria and is widely used in human and veterinary medicine. This ATB is also applied in intensive livestock and aquaculture farming for growth promotion and feed efficiency (Jessick et al., 2011).

ERY is slightly absorbed by humans and animals and is excreted in urine (5-10\%) and faeces (50-67\%) (McArdell et al., 2003). The elimination/degradation of this macrolide in wastewater treatment plants is incomplete (Kolpin et al., 2002). Thus, ERY has been one of most widespread antibiotic found in aquatic systems: surface, groundwater and drinking water (Hirsch et al., 1999; Christian et al., 2003; Xue et al., 2013; Jiang et al., 2014; Schafhauser et al., 2018). ERY tends to persist in aquatic systems (Zuccato et al., 2005), being detected in concentrations of ng $\mathrm{L}^{-1}$ to $\mu \mathrm{g} \mathrm{L}^{-1}$ (Kolpin et al., 2002; Zhang et al., 2013). Although there are no legal limits of discharge into the environment, ERY was included in the watch list of substances/group of substances for extent monitoring by the Decision 2018/840/EU of European Comission (2018). Due to its continuous and increased use, detection in environment, persistence and toxic effects detected at low concentrations, ERY is considered a contaminant of emerging and high ecotoxicological concern (Milić et al., 2013; Välitalo et al., 2017).

It has been shown that antibiotics, at low concentrations, influence bacterial cell physiology (morphology, macromolecular composition and metabolism) and gene expression (Mitosch and Bollenbach, 2014). The changes in bacterial populations cause impact on nutrient cycle (Ding and He, 2010; Martínez, 2017). Additionally, the presence of ERY in aquatic systems may cause adverse effects on aquatic, non-target organisms (Välitalo et al., 2017). In this context, it is described that ERY disturbed cyanobacterial growth (Ando et al., 2007; González-Pleiter et al., 2013, 2017a; Waiser et al., 2016). ERY also inhibited the electron transport of both photosystems (PSI and PSII) of the cyanobacteria

\footnotetext{
* Corresponding authors.

E-mail addresses: mmmachado@net.sapo.pt (M.D. Machado), evs@isep.ipp.pt (E.V. Soares).
} 
Microcystis aeruginosa in a concentratioh-dependent way (Deng et al., 2014). This antibiotic interfered with the chlorophyll $a$ biosynthesis and caused oxidative stress in the cyanobacterium Microcystis flos-aquae (Wan et al., 2015). Other studies also reported that ERY inhibited growth (Eguchi et al., 2004; Isidori et al., 2005; Sendra et al., 2018), affected photosynthesis (Liu et al., 2011b; Sendra et al., 2018) and antioxidant systems (Nie et al., 2013; Sendra et al., 2018) in microalgal cells. Chronic exposure to ERY lead to a reduction of viability of the freshwater invertebrate Daphnia magna (water flea) (Ji et al., 2012).

Microalgae, as primary producers, constitute the basis of food chain. These microorganisms have been considered a good indicator of anthropogenic pollution and are used in the assessment of water quality. Thus, the microalga Pseudokirchneriella subcapitata has been applied as a reference organism in standard toxicity tests (OECD, 2011; US-EPA, 2012) due to its ease of culturing, ubiquitous distribution and high sensitivity to toxic substances including metals and organic contaminants (Rojickova-Padrtova and Marsalek, 1999).

Due to its action mechanism, it could be expected that ERY inhibits the growth of cyanobacteria (a prokaryotic cell). However, it is unpredictable what effect ERY could have on eukaryotic aquatic organisms. Therefore, there is the need to study how microalgae respond to increased concentrations of ERY for a better knowledge regarding the risks that this antibiotic might pose to non-target organisms in aquatic ecosystems.

Our previous study reported that ERY inhibits the growth of $P$. subcapitata (72 h-EC values) at environmentally relevant concentrations, i.e., at concentrations detected in freshwaters (Machado and Soares, 2019). In the present work, it was our objective to study the modes of action of ERY on a non-target organism, the freshwater microalga $P$. subcapitata. For this aim, algal cells were exposed for $72 \mathrm{~h}$ to different concentrations of ERY and the following physiological and biochemical parameters were evaluated: cell morphology (biovolume), viability, metabolic activity, chlorophyll $a$ (chl a) content, photosynthetic and mitochondrial activity, reactive oxygen species (ROS) production and intracellular reduced glutathione (GSH) content.

\section{Material and methods}

\subsection{Strain, media and culture conditions}

This work was performed using the freshwater green alga Pseudokirchneriella subcapitata (strain 278/4) acquired from the Culture Collection of Algae and Protozoa (CCAP), UK.

The alga was maintained in OECD medium (OECD, 2011) with $20 \mathrm{~g} \mathrm{~L}^{-1}$ agar (Merck), in the dark, at $4{ }^{\circ} \mathrm{C}$. Medium stock solutions were prepared and stored as defined by OECD guidelines (OECD, 2011). Precultures and cultures with an initial cell concentration of $\sim 5 \times 10^{4}$ cells $\mathrm{mL}^{-1}$ were prepared as previously described by Machado and Soares (2012a). Algal cells were incubated for 2 days, at $25^{\circ} \mathrm{C}$, on an orbital shaker at $100 \mathrm{rpm}$, under continuous "cool white" fluorescent light (fluorescent lamps with a colour temperature of $4300 \mathrm{~K}$ ), with an intensity of 4000 lux at the surface of the flasks.

\subsection{Treatment of algal cells with ERY}

Algal cells were exposed for $72 \mathrm{~h}$ to $2.2,5,38$ and $200 \mu \mathrm{g} \mathrm{L}{ }^{-1} \mathrm{ERY}$, which corresponded to $72 \mathrm{~h}-\mathrm{NOEC}, 72 \mathrm{~h}-\mathrm{EC}_{10}, 72 \mathrm{~h}-\mathrm{EC}_{50}$, and $72 \mathrm{~h}$ $\mathrm{EC}_{90}$, respectively (Machado and Soares, 2019). The assays were carried out in $1 \mathrm{~L}$ Erlenmeyer flasks containing OECD medium and the concentrations of ERY reported above in a final volume of $400 \mathrm{~mL}$. The culture medium was inoculated with algal cells in exponential phase of growth (from a 2-day-old culture) at $5 \times 10^{4}$ cells $\mathrm{mL}^{-1}$ and incubated at $25^{\circ} \mathrm{C}$, on an orbital shaker at $100 \mathrm{rpm}$, under continuous "cool white" fluorescent light, as described above. As a control, cells were incubated in the same conditions reported above but without ERY. The ERY stock solution $\left(12.6 \mathrm{~g} \mathrm{~L}^{-1}\right)$ was prepared in dimethyl sulfoxide (DMSO) and stored in the dark, at $-20^{\circ} \mathrm{C}$. Working solutions ( 5 and $20 \mathrm{mg} \mathrm{L}^{-1}$ ) of ERY were prepared in water and stored in the dark at $4{ }^{\circ} \mathrm{C}$. In the assays, the final concentration of DMSO was less than $0.002 \%(\mathrm{v} / \mathrm{v})$. Control experiments, previously done, with DMSO showed that, in the concentrations used, the solvent does not affect the growth of $P$. subcapitata (Machado and Soares, 2019).

For algal growth kinetic assay, samples were withdrawn, at $0,7,24$, $31,48,55$ and $72 \mathrm{~h}$ and cell concentration was measured using an automated cell counter.

The specific growth rates $(\mu)$ were calculated by least-square fitting to the linear part of the semi logarithmic growth plots of the number of cells $\mathrm{mL}^{-1}$ versus time. The doubling time (the time it takes for the algal population to double the cell number) or generation time (g) was calculated using the Eq. (1):

$g=\ln 2 / \mu$

After $72 \mathrm{~h}$ of incubation with the different ERY concentrations, the number of cells in the culture medium was quantified as described above. Then, cells were harvested by centrifugation ( $2500 \times g$, $5 \mathrm{~min}$ ) and resuspended at $\sim 1 \times 10^{6}$ cells $\mathrm{mL}^{-1}$, in $100 \mathrm{mmol} \mathrm{L}^{-1} \mathrm{PBS}$ buffer, pH 7.0 (for subsequent ROS determination), or in OECD medium for subsequent determination of cell viability, biovolume, autofluorescence, metabolic activity, mitochondrial membrane potential and glutathione content. For chlorophyll $a$ determination, cells were suspended at $\sim 3 \times 10^{6}$ cells $\mathrm{mL}^{-1}$ in OECD medium.

\subsection{Assessment of cell viability}

Algal cell viability was accessed through the evaluation of plasma membrane integrity. Cells $\left(1 \times 10^{6} \mathrm{~mL}^{-1}\right)$ were stained with $0.5 \mu \mathrm{mol}$ $\mathrm{L}^{-1}$ SYTOX Green (SG) (Molecular Probes) for $20 \mathrm{~min}$, at $25^{\circ} \mathrm{C}$, in the dark as previously described (Machado and Soares, 2012a). The cells were observed using a Leica DLMB epifluorescence microscope, equipped with a HBO-100 mercury lamp and a filter set GFP (excitation filter BP 470/40, dichromatic mirror 500 and suppression filter BP 525/ 550 ).

Algal cells with permeabilized membrane, i.e., heat-treated at $65{ }^{\circ} \mathrm{C}$ for $1 \mathrm{~h}$ as described by Machado and Soares (2012a) were used as positive control. As negative control (cells with an intact cell membrane), algal cells not exposed to ERY were also used. In each experiment and for each ERY concentration and control, at least three samples of 100 cells (total of $>300$ cells) were scored in randomly selected microscope fields.

\subsection{Biovolume determination}

For the determination of algal cell volume (cells non-treated and treated with ERY), several photos were taken in random fields, in a phase-contrast microscopy using N plan X100 objective. The images were acquired with a Leica DC $300 \mathrm{~F}$ camera and treated using Leica IM 50-Image manager software.

Algal cell volume was calculated based on the assumption that $P$. subcapitata commonly conforms to the shape of a sickle-shaped cylinder (Sun and Liu, 2003). A minimum sample of 300 cells, for each ERY concentration and in each experiment, was analysed.

Cell volume (V) was calculated using the Eq. (2):

$\mathrm{V} \approx(\pi / 6) \cdot a \cdot b^{2}$

where $a$ and $b$ are cell apical section view (length) and transapical section (width), respectively.

For each ERY concentration and control, the relative frequency (i.e. the $\%$ of the number of times) of each volume was calculated. 


\subsection{Chlorophyll a content and autofluorescence of algal cells}

The determination of chl $a$ content was performed as previously described by Soto et al. (2011). Algal cells $\left(3 \times 10^{6} \mathrm{~mL}^{-1}\right)$ were treated with $90 \%(\mathrm{v} / \mathrm{v})$ of acetone for $20 \mathrm{~h}$, at $4{ }^{\circ} \mathrm{C}$, in the dark. Then, cells were centrifuged and the absorbance of the supernatant was measured at 630, 647, 664 and $691 \mathrm{~nm}$. Absorbance was corrected (for turbidity) by subtracting the value of absorbance at $750 \mathrm{~nm}$. Chl $a$ content was calculated as described by Ritchie (2008).

For the chl $a$ fluorescence (autofluorescence) measurement, algal cells $\left(1 \times 10^{6} \mathrm{~mL}^{-1}\right)$ were placed in quintuplicate in a transparent 96 well flat bottom microplate (Orange Scientific). Fluorescence intensity (in relative fluorescence units, RFU) was measured at a fluorescence excitation wavelength of $485 / 14 \mathrm{~nm}$ and an emission wavelength of $680 / 10 \mathrm{~nm}$ using a PerkinElmer (Victor ${ }^{3}$ ) microplate reader.

\subsection{Metabolic activity determination}

Metabolic activity was evaluated using a fluorescein diacetate (FDA)-based esterase assay. Algal cells $\left(5 \times 10^{5} \mathrm{~mL}^{-1}\right)$ were incubated with FDA (Sigma-Aldrich) at a final concentration of $20 \mu \mathrm{mol} \mathrm{L}^{-1}$, in the dark at $25^{\circ} \mathrm{C}$ for $40 \mathrm{~min}$, as previously described by Machado and Soares (2013). Cells not exposed to ERY (positive control) and heat treated at $65^{\circ} \mathrm{C}$ for $1 \mathrm{~h}$ (negative control) were also used.

In order to determine the influence of ERY on the hydrolysis of FDA and on the fluorescence of fluorescein, abiotic controls (without cells) were carried out, using different concentrations of ERY and FDA or fluorescein, respectively. Fluorescein was obtained by deacetylation of FDA using a procedure similar to that described by Aruoja et al. (2015) to $\mathrm{H}_{2}$ DCFDA deacetylation. Briefly, $1 \mathrm{~mL}$ of FDA $\left(1 \mathrm{mmol} \mathrm{L}^{-1}\right)$ was freshly deacetylated to fluorescein by reaction with $4 \mathrm{~mL}$ of $10 \mathrm{mmol}$ $\mathrm{L}^{-1} \mathrm{NaOH}$, in the dark, for $30 \mathrm{~min}$. Then, the reaction was stopped by the addition of $25 \mathrm{mmol} \mathrm{L}^{-1}$ PBS buffer (pH 7.4) to have a $40 \mu \mathrm{mol} \mathrm{L}^{-1}$ FDA solution. This solution was directly protected from light and placed on ice until use. Abiotic FDA hydrolysis assay and fluorescein assay were performed by placing in each well of a 96-well microplate the respective volume of ERY, $100 \mu \mathrm{L}$ of FDA $\left(40 \mu \mathrm{mol} \mathrm{L}^{-1}\right)$ or fluorescein solution $\left(40 \mu \mathrm{mol} \mathrm{L}^{-1}\right)$ and the necessary volume OECD medium to complete $200 \mu \mathrm{L}$. Fluorescence intensity of samples and controls was measured, in quintuplicate, in a microplate reader at a fluorescence excitation wavelength of $485 / 14 \mathrm{~nm}$ and an emission wavelength of $535 / 25 \mathrm{~nm}$.

\subsection{Mitochondrial membrane potential assessment}

The mitochondrial membrane potential $\left(\Delta \Psi_{\mathrm{m}}\right)$ was evaluated using 3,3'-dihexyloxacarbocyanine iodide $\left[\mathrm{DiOC}_{6}(3)\right]$ (Sigma-Aldrich). $\mathrm{DiOC}_{6}(3)$ is a cell-permeant, green fluorescent, lipophilic probe that is selective for mitochondria of live cells (Franklin et al., 2001). Algal cells $\left(1 \times 10^{6} \mathrm{~mL}^{-1}\right)$ in OECD medium were stained with $2.5 \mu \mathrm{mol} \mathrm{\textrm {L } ^ { - 1 }}$ $\mathrm{DiOC}_{6}(3)$ for $10 \mathrm{~min}$ at room temperature in the dark, as previously described (Sousa et al., 2018). As negative control, cells were treated with $50 \mu \mathrm{mol} \mathrm{L}^{-1}$ of carbonyl cyanide $m$-chlorophenyl hydrazine (CCCP, Sigma-Aldrich) (an uncoupler of the proton gradient) for $10 \mathrm{~min}$ and then stained with $\operatorname{DiOC}_{6}(3)$ as described above. CCCP stock solution (5 mmol L ${ }^{-1}$ ) was prepared in dimethyl sulfoxide (DMSO); solvent concentration in the negative control $\leq 1 \%(\mathrm{v} / \mathrm{v})$. Fluorescence was quantified, in quintuplicate, as described in the metabolic activity assessment.

\subsection{Detection of ROS production}

Intracellular ROS accumulation was determined by incubating the algal cells $\left(1 \times 10^{6} \mathrm{~mL}^{-1}\right)$ with $2^{\prime}, 7^{\prime}$-dichlorodihydrofluorescein diacetate $\left(\mathrm{H}_{2}\right.$ DCFDA $)$ in a final concentration of $10 \mu \mathrm{mol} \mathrm{L}^{-1}$ for $90 \mathrm{~min}$ at $25^{\circ} \mathrm{C}$ in the dark, as previously described by Machado and Soares
(2016). Fluorescence intensity was measured, in quintuplicate, as described in the metabolic activity assessment.

\subsection{Evaluation of intracellular reduced glutathione content}

Intracellular reduced glutathione (GSH) content was evaluated using monochlorobimane $(\mathrm{mBCl})$ as previously described by Machado and Soares (2012b). Briefly, algal cells resuspended in OECD medium at $1 \times 10^{6}$ cells $\mathrm{mL}^{-1}$ were incubated with $50 \mu \mathrm{mol} \mathrm{L}^{-1} \mathrm{mBCl}$ at $25^{\circ} \mathrm{C}$ in the dark for $90 \mathrm{~min}$. As negative control, cells were treated with $1 \mathrm{mmol}$ $\mathrm{L}^{-1}$ of iodoacetamide for $1 \mathrm{~h}$, and subsequently stained as describe above. RFU was measured, in quintuplicate, using a microplate reader at a fluorescence excitation of $355 / 40 \mathrm{~nm}$ and an emission of 460 / $25 \mathrm{~nm}$.

\subsection{Expression, reproducibility and statistical analysis of the results}

In metabolic activity, mitochondrial membrane potential, ROS production and intracellular reduced glutathione assessment, fluorescence was corrected (subtracting cell, culture medium and dye fluorescence), normalised (considering the cell concentration) and the results expressed (except for abiotic controls) as the ratio of fluorescence of the assay/fluorescence of the control (cells not exposed to ERY). For chl $a$ content and autofluorescence, the results were normalised (considering the cell concentration) and expressed as the ratio of chl $a$ content or autofluorescence in the assay/chl a content or autofluorescence in the control, respectively. Results are expressed as the mean \pm standard deviation of three to nine independent experiments, carried out under identical conditions. In Figs. 2, 3 and 4, the statistical difference between control and ERY-treated cells were tested using unpaired $t$ test.

\section{Results}

\subsection{Impact of ERY on algal growth, viability and morphology (biovolume)}

In our previous work, the sensitivity of the green alga $P$. subcapitata to the macrolide antibiotic ERY was evaluated; $72 \mathrm{~h}$ growth yield was used as endpoint and the toxicity was expressed as EC values (Machado and Soares, 2019). In order to determine the underlying mechanisms that induced the reduction of growth yield of the alga P. subcapitata, physiological and metabolic changes were evaluated in algal cells exposed for $72 \mathrm{~h}$ to four ERY concentrations: a very low concentration, for which no growth inhibition occur (72 h-NOEC), $2.2 \mu \mathrm{g} \mathrm{L}^{-1}$; a low, $5 \mu \mathrm{g}$ $\mathrm{L}^{-1}$; an intermediate, $38 \mu \mathrm{g} \mathrm{L}^{-1}$ and a high concentration of ERY, $200 \mu \mathrm{g}$ $\mathrm{L}^{-1}$, which correspond to $72 \mathrm{~h}-\mathrm{EC}_{10}, 72 \mathrm{~h}-\mathrm{EC}_{50}$ and $72 \mathrm{~h}-\mathrm{EC}_{90}$ values, respectively (Machado and Soares, 2019).

It is described that ERY is mainly bacteriostatic but can also be bactericidal depending on the species and the antibiotic concentration (Deck and Winston, 2012). In order to elucidate whether ERY exerts an algistatic (hampers the growth) and/or an algaecide (kill the alga) effect, the evolution of algal growth during the exposure to ERY (growth kinetics) was studied. Algal cells exposed to 2.2 or $5 \mu g \mathrm{~L}^{-1}$ ERY presented a growth profile similar to control cells, incubated in the absence of toxic (Fig. 1A). At higher ERY concentrations (38 and $200 \mu \mathrm{g} \mathrm{L}^{-1}$ ), a reduction of algal growth was observed, resulting in an increase of the doubling (generation) time (Fig. 1B). The exposure of algae to $200 \mu \mathrm{g}$ $\mathrm{L}^{-1}$ ERY had as consequence the complete arrest of growth (Fig. 1A) after $24 \mathrm{~h}$ of incubation. These results suggest that ERY exerts an algistatic effect. To confirm this possibility, the evaluation of plasma membrane integrity of algal cells exposed to ERY was carried out through the SYTOX Green uptake assay. It is considered that viable cells, with an intact plasma membrane, exclude SG (SG negative cells); the accumulation of SG (SG positive cells) requires the disruption of plasma membrane (Machado and Soares, 2012a). Cells with an irreparable damage of plasma membrane are considered dead (Galluzzi 


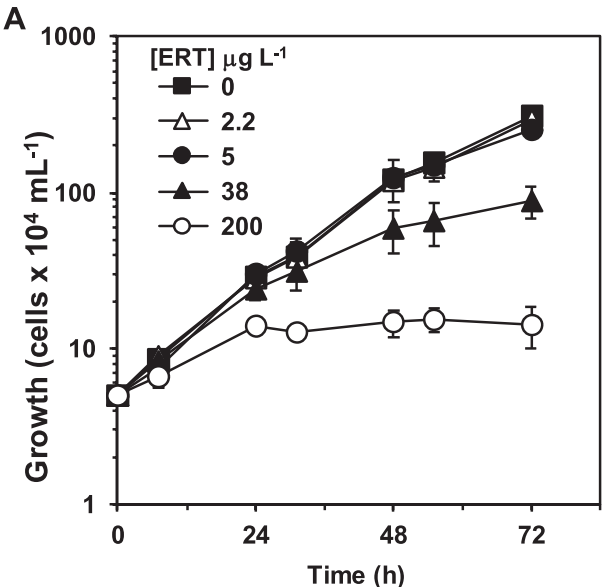

C

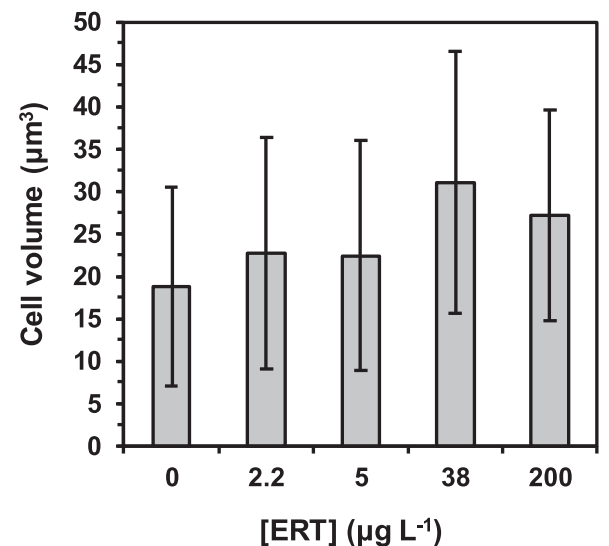

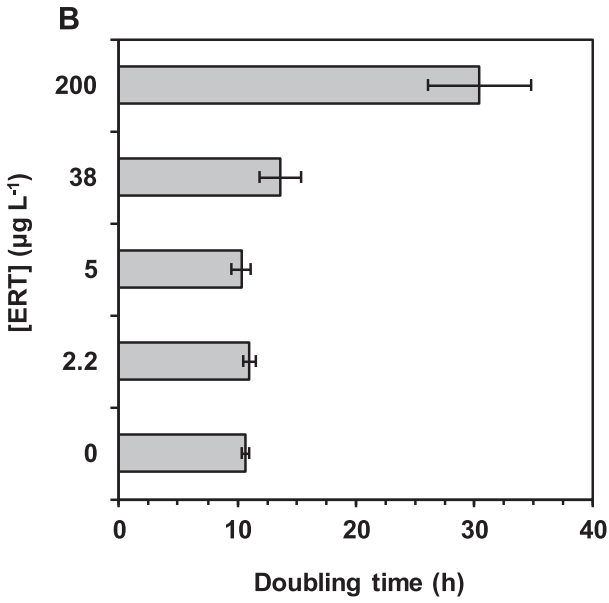

D

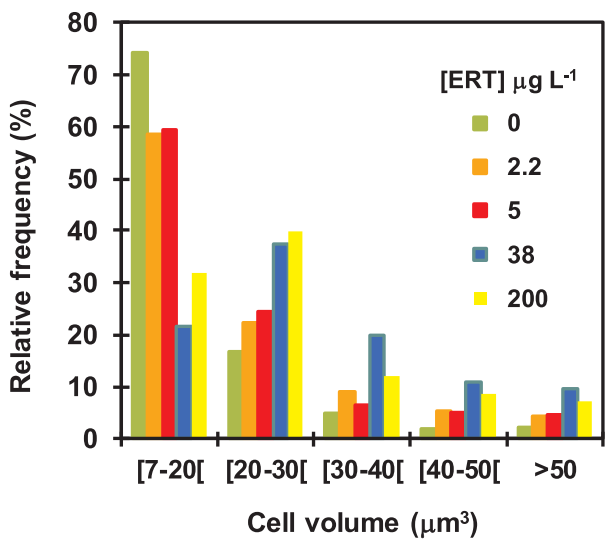

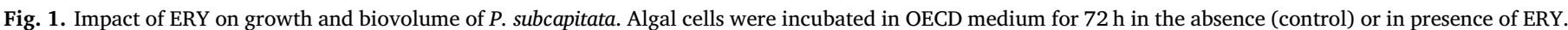

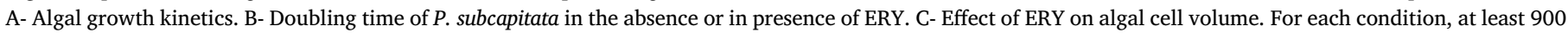

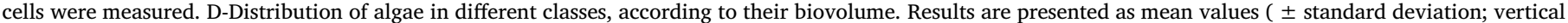
error bars) from three independent experiments.

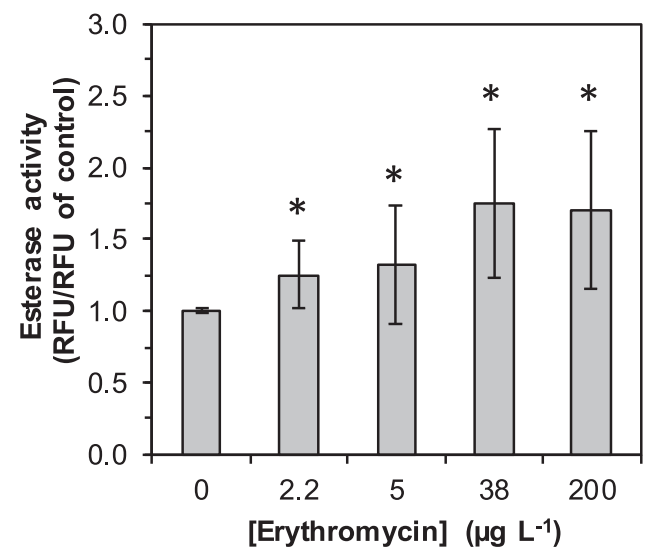

Fig. 2. Effect of ERY on metabolic activity of the alga $P$. subcapitata. Cells were exposed to different concentrations of ERY for $72 \mathrm{~h}$ in OECD medium, and subsequently centrifuged, resuspended in OECD medium and stained with FDA. Results are presented as mean values ( \pm standard deviation; vertical error bars) from nine independent experiments. Statistical differences between control and ERY-treated cells were tested using unpaired $t$ test. The means with $\left({ }^{*}\right)$ are significantly different $(p<0.05)$ from the control.

et al., 2015). Algal cells exposed up to $200 \mu \mathrm{g} \mathrm{L}{ }^{-1}$ ERY, for $72 \mathrm{~h}$, retained their membrane integrity ( $>99 \%$ of cells were SG negative) (Table S1) and, consequently, can be considered viable. This result, together with growth kinetics assay (Fig. 1A), strongly indicates that ERY exhibited an algistatic effect, even at high concentration $\left(200 \mu \mathrm{g} \mathrm{L}^{-1}\right.$ ERY; $72 \mathrm{~h}$ $\mathrm{EC}_{90}$ value).

Algal biovolume was evaluated by microscopy image analysis. Cells not exposed to ERY (control) presented an average volume of $19 \mu \mathrm{m}^{3}$. The algal population presented a wide range of biovolumes: from $7 \mu \mathrm{m}^{3}$ to $>30 \mu \mathrm{m}^{3}$ (Fig. 1C). The exposure of the algae to increasing concentrations of ERY caused a swelling of the cells as shown by the increase of the mean cell volume to $22-31 \mu \mathrm{m}^{3}$. The analysis of the distribution of algal population cell size (relative frequency distribution) confirmed the increase of the size of ERY-treated cells (Fig. 1D). This effect (drift of cell volume to higher values) is particularly evident in ERY-treated cells with a biovolume $>20$ and $<30 \mu \mathrm{m}^{3}$; algal cells treated with 38 or $200 \mu g \mathrm{~L}^{-1}$ ERY presented a higher percentage of cells in this range of biovolume (Fig. 1D). Like in control population, ERY-treated cells also displayed a high heterogeneity of the cell volume (from $7 \mu \mathrm{m}^{3}$ to $>50 \mu \mathrm{m}^{3}$ ).

\subsection{Impact of ERY on algal metabolic activity}

To obtain additional clues regarding the impact of ERY on microalgae, the overall metabolic activity of the cells was studied. Thus, the hydrolysis of FDA by the action of intracellular esterases was quantified. The green fluorescence signal presented by algae can be correlated with their esterase activity (metabolic activity) (Machado and Soares, 2013). The antibiotic ERY induced an increase of the green signal 

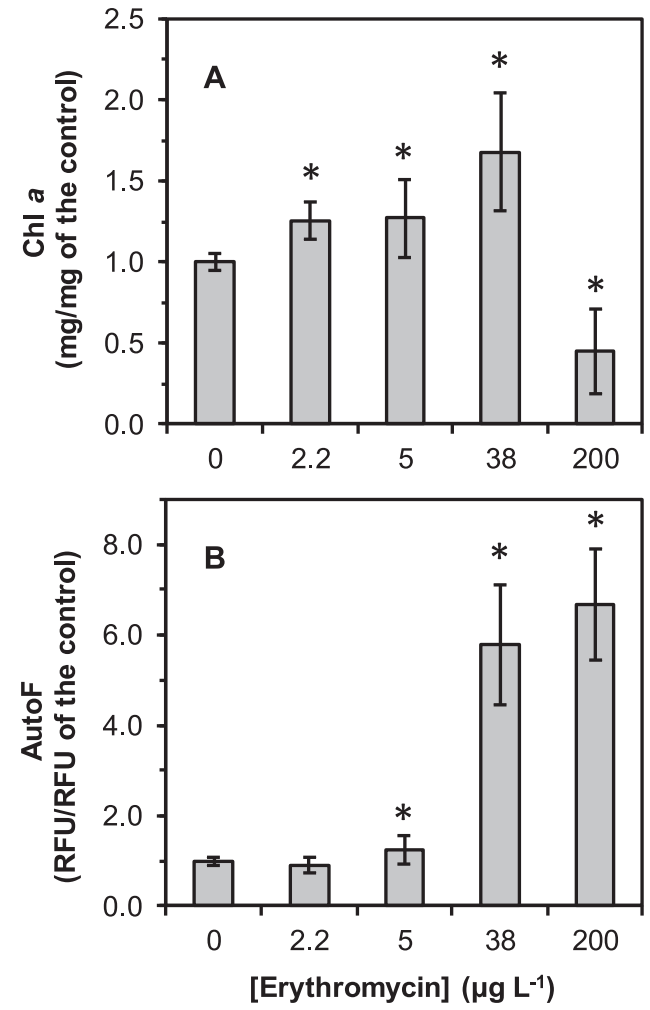

Fig. 3. Influence of ERY on the chlorophyll $a$ content and autofluorescence of the alga $P$. subcapitata. Cells were exposed to different concentrations of ERY for $72 \mathrm{~h}$ in OECD medium. A- Chl $a$ content. B- Algal autofluorescence. Results are presented as mean values ( \pm standard deviation; vertical error bars) from four independent experiments. Statistical differences between control and ERYtreated cells were tested using unpaired $t$ test. The means with $\left(^{*}\right)$ are significantly different $(p<0.05)$ from the control.

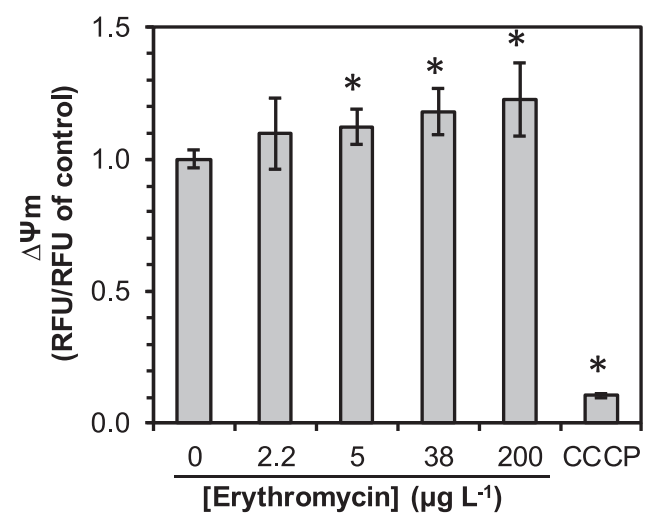

Fig. 4. Impact of ERY on the mitochondrial membrane potential $(\Delta \Psi \mathrm{m})$ of the alga $P$. subcapitata. Cells were exposed to different concentrations of ERY for $72 \mathrm{~h}$, in OECD medium. Subsequently, algal cells were stained with $\mathrm{DiOC}_{6}(3)$. As negative control, cells were treated with $50 \mu \mathrm{mol} \mathrm{L}^{-1}$ CCCP for $10 \mathrm{~min}$ and then stained with $\mathrm{DiOC}_{6}(3)$. Results are presented as mean values ( \pm standard deviation; vertical error bars) from four independent experiments. Statistical differences between control and ERY-treated cells were tested using unpaired $t$ test. The means with $\left(^{*}\right)$ are significantly different $(p<0.05)$ from the control.

emitted by algal cells, indicating a stimulation of the esterase activity, in a concentration-dependent way (Fig. 2). Even for the algal cells incubated at the lowest ERY concentration $\left(2.2 \mu \mathrm{g} \mathrm{L}^{-1}\right)$, where no change of growth was observed, the esterase activity increased $25 \%$ compared to control cultures. Algal cells exposed to higher concentrations of ERY presented a marked increase $(\sim 75 \%)$ of the metabolic activity.

To exclude a possible influence of ERY on FDA-assay, abiotic controls without algal cells were carried out. It was observed that ERY did not interfere with FDA hydrolysis (Fig. S.1 A) or with fluorescein fluorescence (Fig. S.1B). Therefore, the increase of algal fluorescence, in the FDA-assay (Fig. 2), can be most likely attributed to an increase of the esterase activity.

\subsection{Impact of ERY on algal chl a content and autofluorescence}

ERY mechanism of action is associated with its binding to the $50 \mathrm{~S}$ subunit of the bacterial ribosome (Cammack et al., 2006). Since the ribosomes in chloroplasts are similar to bacterial ribosomes (Harris et al., 1994), the impact of ERY on algal photosynthetic activity was study through the quantification of chl $a$ content and the autofluorescence exhibited by algal cells.

The exposure of algal cells to 2.2, 5 and $38 \mu \mathrm{g} \mathrm{L}{ }^{-1}$ ERY induced an increase of chl $a$ content (Fig. 3A). Cells exposed to the highest ERY concentration $\left(200 \mu \mathrm{g} \mathrm{L}^{-1}\right)$, presented a significant reduction of chl $a$ content compared to control cultures.

The level of red autofluorescence exhibited by algae is related with the photochemical activity of photosystem II (PSII) and can be used as biomarker for assessment of negative impacts of toxicants on photosynthesis (Franklin et al., 2001; Fai et al., 2007). An increase of autofluorescence is seen as a sign of photosynthesis disturbance due to the inhibition of the acceptor side of PSII (Yruela et al., 1993). Algae exposed to ERY concentrations between 2.2 and $5 \mu \mathrm{g} \mathrm{L} \mathrm{L}^{-1}$ presented an autofluorescence similar to control cultures (not treated with ERY). An increase of autofluorescence was observed for cells incubated with $38 \mu \mathrm{g} \mathrm{L}^{-1}$ and $200 \mu \mathrm{g} \mathrm{L}^{-1}$ ERY (Fig. 3B).

Together, these data indicate a disturbance of the photosynthetic activity of algal cells exposed to ERY; this perturbation is particularly notorious in algae cultured in the presence of high (38 and $200 \mu \mathrm{g} \mathrm{L}^{-1}$ ) ERY concentrations.

\subsection{Impact of ERY on mitochondrial membrane potential}

Similarly to chloroplasts, mitochondrial ribosomes resemble bacterial ribosomes (Lodish et al., 2008). Therefore, the possible impact of ERY on mitochondria was assessed through the evaluation of the mitochondrial membrane potential $\left(\Delta \Psi_{\mathrm{m}}\right) \cdot \mathrm{DiOC}_{6}(3)$ is a fluorescent cationic probe which accumulates in mitochondria due to their high negative membrane potential and can be applied to monitor $\Delta \Psi_{\mathrm{m}}$ (Haughland, 2005). A significant increase of fluorescence signal was observed in algal cells exposed to ERY, suggesting a hyperpolarization of the mitochondrial membrane (increase of $\Delta \Psi_{\mathrm{m}}$ ) of $P$. subcapitata. This effect was more evident in algal cells exposed to 38 or $200 \mu \mathrm{g} \mathrm{L}^{-1}$ ERY (Fig. 4).

\subsection{Impact of ERY on intracellular ROS accumulation and GSH content}

The intracellular accumulation of reactive oxygen species (ROS) was monitored using the general redox sensor $\mathrm{H}_{2}$ DCFDA (Tarpey et al., 2004). For all ERY concentrations, despite the big dispersion of the results observed, a substantial modification of intracellular ROS levels was not detected compared to the control (cells not exposed to ERY) (Fig. 5A).

Reduced glutathione (GSH) is an important antioxidant, capable of preventing the damage to cellular components caused by ROS (Kerksick and Willoughby, 2005). Intracellular GSH content of the algal cells of $P$. subcapitata was evaluated using the monochlorobimane dye. The incubation of algal cells with ERY up to $5 \mu \mathrm{L} \mathrm{L}^{-1}$ did not affect GSH content (Fig. 5B). However, algae cultured in the presence of $38 \mu \mathrm{g} \mathrm{L}^{-1}$ ERY, presented a significant increase of intracellular GSH content, comparatively to control. For the higher ERY concentration tested $\left(200 \mu \mathrm{g} \mathrm{L}^{-1}\right)$, no modification of GSH content was observed. 

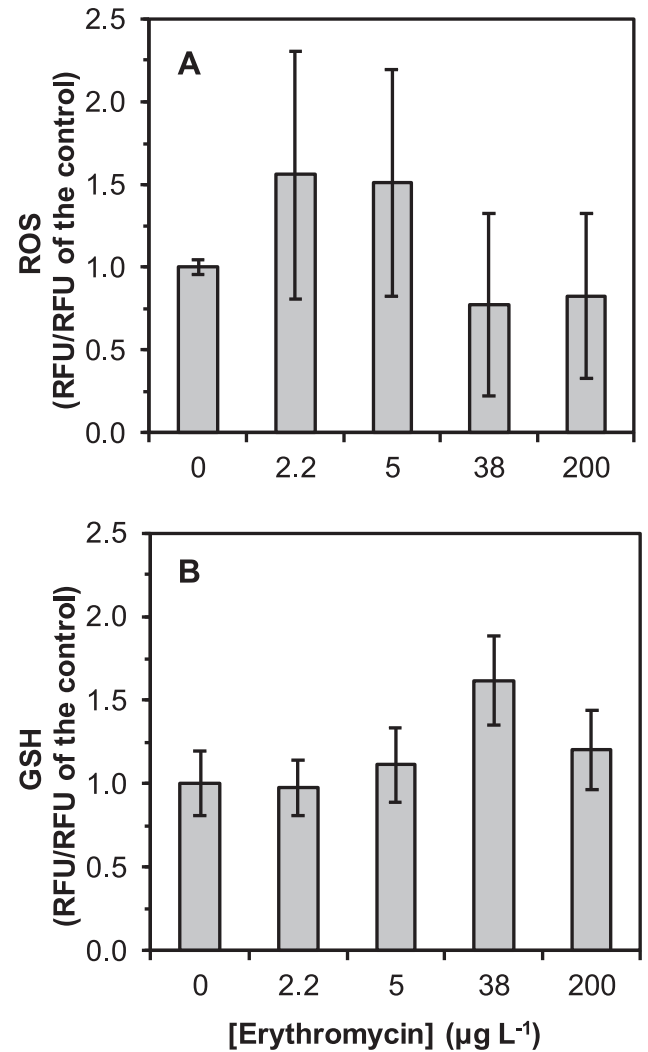

Fig. 5. Impact of ERY on ROS production and GSH content of the alga $P$. subcapitata.

Cells were exposed to different concentrations of ERY for $72 \mathrm{~h}$ in OECD medium; subsequently, cells were resuspended in PBS buffer (ROS) or OECD medium (GSH) and stained with $\mathrm{H}_{2}$ DCFDA or with monochlorobimane, respectively. A - Intracellular ROS accumulation. B- Intracellular reduced glutathione. Results are presented as mean values ( \pm standard deviation; vertical error bars) from four-six independent experiments.

\section{Discussion}

Due to its increased use, not only in the fight against human bacterial infections, but also to promote the increase of growth rates in livestock and to prevent bacterial crop damages, antibiotics are widespread in aquatic systems (ground, surface and even drinking water). Macrolides are one of the classes of antibiotics most frequently detected in the environment (Halling-Sorensen et al., 1998; Hirsch et al., 1999; Pérez et al., 2017).

Research has been mainly focused on the study of the resistance of bacteria to antibiotics and its consequences for humans (Chang et al., 2015). Although this is a paramount issue, the presence of antibiotics in aquatic environments can cause a serious threat for all food chain. So, it is of high importance to study the impact of antibiotics on other (nontarget) organisms (Välitalo et al., 2017). Thereby, it was our objective to contribute for the elucidation of the modes of action of the macrolide ERY on a non-target organism: the freshwater alga $P$. subcapitata. Microalgae are primary producers and constitute the basis of food chain being one of the first organisms to be exposed to toxicants, which increases their importance in the evaluation of the possible toxic effects in the environment.

Although more than $95 \%$ of proteins localized in the chloroplasts are encoded by nuclear genes, synthesized on cytosolic ribosomes as precursor proteins and imported into the organelle (Soll and Schleiff, 2004; Shi and Theg, 2013), chloroplasts have their own genome. In the case of the single-cell green alga Chlamydomonas reinhardtii, chloroplast DNA (cpDNA) encodes, as an example, for polypeptides identified as subunits of multimeric complexes involved in the PSI si and PSII, the cytochrome $b / f$ complex, the complex ATP synthase and for the large subunit of the enzyme ribulose-1,5-bisphosphate carboxylase/oxygenase (RuBisCo) (Maul et al., 2002; Gallaher et al., 2018). All proteins encoded by cpDNA are synthesized in chloroplasts. Reflecting the bacterial ancestry, ribosomes present in chloroplasts resemble bacterial ribosomes (Harris et al., 1994; Reyes-Prieto et al., 2007). Therefore, the sensitivity of chloroplast ribosomes to ERY can be in the origin of the toxicity that this ATB can cause in a non-target organism (P. subcapitata algal cells). Consistent with this possibility, a disturbance of photosynthesis, revealed by an increase of autofluorescence, in algal cells exposed to 38 and $200 \mu \mathrm{gL}^{-1} \mathrm{ERY}$ was observed (Fig. 3A). The increase of algal autofluorescence occurs as a result of the reduction of photosynthesis efficiency (Fai et al., 2007) and is usually attributed to the inhibition in the photochemical activity of PSII, the first protein-complex in the light-dependent reactions of photosynthesis (Yruela et al., 1993; Samson et al., 2018). The inhibition of photosynthesis here observed is in agreement with the results presented in the literature reporting the perturbation of photosynthetic apparatus of the alga $P$. subcapitata exposed to $60 \mu \mathrm{g} \mathrm{L}{ }^{-1} \mathrm{ERY}$ for $96 \mathrm{~h}$ (Liu et al., 2011b). Similarly, it has also been reported that some antibiotics (amoxicillin and chloramphenicol) can inhibit photosynthesis in plants and in cyanobacteria by blocking the PSII electron transport chain, which inhibits the transfer of electrons from chlorophyll to the PSI sireaction centre (Okada et al., 1991; Pan et al., 2008).

Chlorophyll biosynthesis is a complex process involving 15 steps catalysed by enzymes encoded by both chloroplast and nuclear genes (Beale, 2005). P. subcapitata algal cells exposed to ERY presented a dual response: chl $a$ content increased for $38 \mu \mathrm{L} \mathrm{L}^{-1} \mathrm{ERY}\left(72 \mathrm{~h}-\mathrm{EC}_{50}\right)$ and decreased for $200 \mu \mathrm{g} \mathrm{L}^{-1}$ ERY (72 h-EC 90 ) (Fig. 3B). The first stage of photosynthesis is the absorption of light by photosynthetic pigments that are attached to proteins in the thylakoid membranes of chloroplasts. The increase in chl $a$ content in cells exposed to $38 \mu \mathrm{g} \mathrm{L}^{-1}$ ERY could be seen as a homeostatic mechanism to compensate for the photosynthesis inhibition. At higher ERY concentration $\left(200 \mu \mathrm{g} \mathrm{L}^{-1}\right)$ the cells became unable to compensate for the reduction of photosynthetic efficiency. Most likely, ERY at high concentrations induced a decrease of chl $a$ content in algal cells through the inhibition of protein synthesis in chloroplast ribosomes. The results presented are in agreement with those reporting the inhibition of photosynthetic pigments, including chl $a$, in $P$. subcapitata algal cells exposed to high concentrations of ERY ( $>60 \mu \mathrm{g} \mathrm{L}^{-1}$ ) for $96 \mathrm{~h}$ (Liu et al., 2011a). In a recent work, a modification of expression of genes involved in photosynthesis of the alga Chlamydomonas reinhardtii after the exposure to the antiseptic triclosan was described (González-Pleiter et al., 2017b).

Like chloroplasts, the proteins present in mitochondria have a dual genetic origin: mitochondrial and nuclear. In the alga $C$. reinhardtii, the mitochondrial genome has eight protein-coding genes, associated for instance, with complex I (NADH dehydrogenase), complex II $\left(\mathrm{CoQH}_{2}-\right.$ cytochrome $c$ reductase) and complex IV (cytochrome $c$ oxidase) of electron transport chain (Gallaher et al., 2018). All proteins encoded by mitochondrial DNA are synthesized by mitochondrial ribosomes, which also resemble bacterial ribosomes (Lodish et al., 2008; Andreux et al., 2013). The sensitivity of mitochondrial ribosomes to ERY, and the consequent inhibitory effect on protein synthesis (de Vries et al., 1973), can cause a perturbation of mitochondrial activity. Compatible with this possibility, it was observed the hyperpolarization of mitochondrial inner membrane (increase of mitochondrial transmembrane potential, $\Delta \Psi_{\mathrm{m}}$ ) in algal cells treated with 5-200 $\mu \mathrm{g} \mathrm{L} \mathrm{L}^{-1}$ ERY (Fig. 4), which suggests a mitochondrial dysfunction. Mitochondrial hyperpolarization has been observed in a wide variety of cells; it was associated with the inhibition of the complex I of electron transport chain and a reduction of ATP level (Forkink et al., 2014).

In algal cells, ROS generation is mainly attributed to the disturbance of the normal functioning of PSII or PSI siin the chloroplast thylakoids, and respiratory chain in mitochondria (Apel and Hirt, 2004; Asada, 2006). Although a perturbation of the activity of chloroplasts and 
mitochondria was observed in ERY treated cells, a clear image about the modification of the intracellular level of ROS in algal cells treated with ERY, did not emerge (Fig. 5A). Interestingly, GSH content did not follow an identifiable pattern in algal cells exposed to ERY, either (Fig. 5B). The increase of intracellular levels of ROS, induced by chemical or physical stressors, is usually one of the main reasons of loss of cell membrane integrity, via lipid peroxidation and cell death (Valavanidis et al., 2006). The present results suggest that oxidative stress is not in the basis of the toxic effects found in P. subcapitata cells treated with ERY. Consistent with this possibility, it was observed that algal cells exposed up to $200 \mu \mathrm{g} \mathrm{L}^{-1}$ ERY conserved an intact plasma membrane, as evaluated by their impermeability to SG (Table S1).

Algal cells exposed to 38 or $200 \mu \mathrm{g} \mathrm{L}^{-1}$ ERY presented a reduction of growth rate (Fig. 1B), which was accompanied with an increase of biovolume (Fig. 1C,D) in the absence of loss of viability (Table S1). Such algistatic effect can be attributed to a reduction of the energetic state of the cells as consequence of the disturbance of photosynthetic and mitochondrial activity. Most likely, the reduction of the energetic state of the cells impairs algal growth through the inhibition of algal cell division. It was described that the hindrance of algal cell cycle progress, as a consequence to the exposure to metals or NiO nanoparticles, resulted as cells with an increased biovolume and aberrant morphology (Machado and Soares, 2014; Sousa et al., 2018).

The exposure of algal cells to ERY induced an increase of esterase activity (Fig. 2). The intensification of esterase activity may be the consequence of the disturbance of algal metabolism or the accumulation of the enzymes due to the inhibition of cell separation.

\section{Conclusion}

The present work offered several evidences regarding the impact of ERY at low levels (within the range of the concentrations found in surface and ground waters) on relevant cell targets of the alga $P$. subcapitata. Probably, ERY inhibited the protein synthesis in the prokaryotic-like ribosomes, present in chloroplasts and mitochondria of algal cells, resulting in a disturbance of photosynthetic and mitochondrial activity. The dysfunction of these organelles, most likely, caused a decrease of cell energy level (ATP) which had as consequence the reduction of cell growth rate through the impairment of cell division, rendering cells with an increased biovolume. ERY exerted an algistatic effect: reduced or impaired algal growth, in the absence of a loss of membrane integrity; i.e., algal cells lost their proliferation capacity but remained viable. The present work contributes to the elucidation of the mechanisms of action underlying the ERY toxicity to a non-target, aquatic organism: the freshwater alga $P$. subcapitata. In addition, it raised awareness for the potential negative impacts that ERY may cause on aquatic systems.

\section{Conflict of interest}

The authors have declared no conflict of interest.

\section{Acknowledgments}

This study was supported by the Portuguese Foundation for Science and Technology (FCT) under the scope of the strategic funding of UID/ BIO/04469/2013 unit and COMPETE 2020 (POCI-01-0145-FEDER006684) and BioTecNorte operation (NORTE-01-0145-FEDER-000004) funded by the European Regional Development Fund under the scope of Norte2020 - Programa Operacional Regional do Norte. Manuela D. Machado gratefully acknowledges the post-doctoral grant from FCT (SFRH/BPD/72816/2010).

\section{Appendix A. Supplementary data}

Supplementary material related to this article can be found, in the online version, at doi:https://doi.org/10.1016/j.aquatox.2019.01.014.

\section{References}

Ando, T., Nagase, H., Eguchi, K., et al., 2007. A novel method using cyanobacteria for ecotoxicity test of veterinary antimicrobial agents. Environ. Toxicol. Chem. 26, 601-606. https://doi.org/10.1897/06-195R.1.

Andreux, P.A., Houtkooper, R.H., Auwerx, J., 2013. Pharmacological approaches to restore mitochondrial function. Nat. Rev. Drug Discov. 12, 465-483. https://doi.org/ $10.1038 / \mathrm{nrd} 4023$.

Apel, K., Hirt, H., 2004. Reactive oxygen species: metabolism, oxidative stress, and signal transduction. Annu. Rev. Plant Biol. 55, 373-399. https://doi.org/10.1146/annurev. arplant.55.031903.141701.

Aruoja, V., Pokhrel, S., Sihtmaae, M., et al., 2015. Toxicity of 12 metal-based nanoparticles to algae, bacteria and protozoa. Environ. Sci. 2, 630-644. https://doi.org/ 10.1039/c5en00057b.

Asada, K., 2006. Production and scavenging of reactive oxygen species in chloroplasts and their functions. Plant Physiol. 141, 391-396. https://doi.org/10.1104/pp.106. 082040 .

Beale, S.I., 2005. Green genes gleaned. Trends Plant Sci. 10, 309-312. https://doi.org/10. 1016/j.tplants.2005.05.005.

Cammack, R., Atwood, T., Campbell, O., et al., 2006. Oxford Dictionary of Biochemistry and Molecular Biology, 2nd ed. Oxford University Press, pp. 225. https://doi.org/10. 1093/acref/9780198529170.001.0001.

Chang, Q., Wang, W., Regev-Yochay, G., et al., 2015. Antibiotics in agriculture and the risk to human health: how worried should we be? Evol. Appl. 8, 240-247. https:// doi.org/10.1111/eva.12185.

Christian, T., Schneider, R.J., Farber, H.A., et al., 2003. Determination of antibiotic residues in manure, soil, and surface waters. Acta Hydrochim. Hydrobiol. 31, 36-44. https://doi.org/10.1002/aheh.200390014.

Davies, J., Davies, D., 2010. Origins and evolution of antibiotic resistance. Microbiol. Mol. Biol. Rev. 74, 417-433. https://doi.org/10.1128/MMBR.00016-10.

de Vries, H., Arendzen, A.J., Kroon, A.M., 1973. The interference of the macrolide antibiotics with mitochondrial protein synthesis. Biochim. Biophys. Acta 331, 264-275. https://doi.org/10.1016/0005-2787(73)90439-5.

Deck, D.H., Winston, L.G., 2012. Tetracyclines, macrolides, clindamycin, chloramphenicol, streptogramins and oxazolidinones. In: Katzung, B.G., Masters, S.B., Trevor, A.J. (Eds.), Basic \& Clinical Pharmacology, 12th edn. McGraw-Hill, pp. 809-818.

Deng, C.N., Zhang, D.Y., Pan, X.L., 2014. Toxic effects of erythromycin on photosystem I and II in Microcystis aeruginosa. Photosynthetica 52, 574-580. https://doi.org/10. 1007/s11099-014-0063-4.

Ding, C., He, J., 2010. Effect of antibiotics in the environment on microbial populations. Appl. Microbiol. Biotechnol. 87, 925-941. https://doi.org/10.1007/s00253-010 2649-5.

Eguchi, K., Nagase, H., Ozawa, M., et al., 2004. Evaluation of antimicrobial agents for veterinary use in the ecotoxicity test using microalgae. Chemosphere $57,1733-1738$. https://doi.org/10.1016/j.chemosphere.2004.07.017.

European Comission, 2018. Comission Decision (EU) 2018/840 of 5 June 2018 Establishing a Watch List of Substances for Union-wide Monitoring in the Field of Water Policy Pursuant to Directive 2008/105/EC of the European Parliament and of the Council and Repealing Commission Implementing Decision (EU) 2015/495.

Fai, P.B., Grant, A., Reid, B., 2007. Chlorophyll $a$ fluorescence as a biomarker for rapid toxicity assessment. Environ. Toxicol. Chem. 26, 1520-1531. https://doi.org/10. 1897/06-394R1.1.

Forkink, M., Manjeri, G.R., Liemburg-Apers, D.C., et al., 2014. Mitochondrial hyperpolarization during chronic complex I inhibition is sustained by low activity of complex II, III, IV and V. Biochim. Biophys. Acta 1837, 1247-1256. https://doi.org/10.1016/j. bbabio.2014.04.008.

Franklin, N.M., Stauber, J.L., Lim, R.P., 2001. Development of flow cytometry-based algal bioassays for assessing toxicity of copper in natural waters. Environ. Toxicol. Chem. 20, 160-170. https://doi.org/10.1002/etc.5620200118.

Gallaher, S.D., Fitz-Gibbon, S.T., Strenkert, D., et al., 2018. High-throughput sequencing of the chloroplast and mitochondrion of Chlamydomonas reinhardtii to generate improved de novo assemblies, analyze expression patterns and transcript speciation, and evaluate diversity among laboratory strains and wild isolates. Plant J. 93, 545-565. https://doi.org/10.1111/tpj.13788.

Galluzzi, L., Bravo-San Pedro, J.M., Vitale, I., et al., 2015. Essential versus accessory aspects of cell death: recommendations of the NCCD 2015. Cell Death Differ. 22, 58-73. https://doi.org/10.1038/cdd.2014.137.

González-Pleiter, M., Gonzalo, S., Rodea-Palomares, I., et al., 2013. Toxicity of five antibiotics and their mixtures towards photosynthetic aquatic organisms: implications for environmental risk assessment. Water Res. 47, 2050-2064. https://doi.org/10. 1016/j.watres.2013.01.020.

González-Pleiter, M., Leganés, F., Fernández-Piñas, F., 2017a. Intracellular free $\mathrm{Ca}^{2+}$ signals antibiotic exposure in cyanobacteria. RSC Adv. 7, 35385-35393. https://doi. org/10.1039/c7ra03001k.

González-Pleiter, M., Rioboo, C., Reguera, M., et al., 2017b. Calcium mediates the cellular response of Chlamydomonas reinhardtii to the emerging aquatic pollutant Triclosan. Aquat. Toxicol. 186, 50-66. https://doi.org/10.1016/j.aqtox.2017.02.021.

Halling-Sorensen, B., Nielsen, S.N., Lanzky, P.F., et al., 1998. Occurrence, fate and effects of pharmaceutical substances in the environment - a review. Chemosphere 36, 357-394. https://doi.org/10.1016/S0045-6535(97)00354-8.

Harris, E.H., Boynton, J.E., Gillham, N.W., 1994. Chloroplast ribosomes and protein synthesis. Microbiol. Rev. 58 (700) LP-754. 
Haughland, R.P., 2005. The Handbook - A Guide to Fluorescent Probes and Labelling Technologies, 10th ed. Invitrogen Corp., Eugene, OR, USA.

Hirsch, R., Ternes, T., Haberer, K., et al., 1999. Occurrence of antibiotics in the aquatic environment. Sci. Total Environ. 225, 109-118. https://doi.org/10.1016/S0048 9697(98)00337-4.

Isidori, M., Lavorgna, M., Nardelli, A., et al., 2005. Toxic and genotoxic evaluation of six antibiotics on non-target organisms. Sci. Total Environ. 346, 87-98. https://doi.org/ 10.1016/j.scitotenv.2004.11.017

Jessick, A.M., Moorman, T.B., Coats, J.R., 2011. Optimization of analytical methods to improve detection of erythromycin from water and sediment. J. Environ. Sci. Health B 46, 735-740. https://doi.org/10.1080/03601234.2011.603974.

Ji, K., Kim, S., Han, S., et al., 2012. Risk assessment of chlortetracycline, oxytetracycline, sulfamethazine, sulfathiazole, and erythromycin in aquatic environment: are the current environmental concentrations safe? Ecotoxicology 21, 2031-2050. https:// doi.org/10.1007/s10646-012-0956-6.

Jiang, Y., Li, M., Guo, C., et al., 2014. Distribution and ecological risk of antibiotics in a typical effluent - receiving river (Wangyang River) in north China. Chemosphere 112, 267-274. https://doi.org/10.1016/j.chemosphere.2014.04.075.

Kerksick, C., Willoughby, D., 2005. The antioxidant role of glutathione and N-acetylcysteine supplements and exercise-induced oxidative stress. J. Int. Soc. Sports Nutr. 2, 38-44. https://doi.org/10.1186/1550-2783-2-2-38.

Kolpin, D.W., Furlong, E.T., Meyer, M.T., et al., 2002. Pharmaceuticals, hormones, and other organic wastewater contaminants in U.igS. streams, 1999-2000: a nationa reconnaissance. Environ. Sci. Technol. 36, 1202-1211. https://doi.org/10.1021/ es011055j.

Liu, B., Liu, W., Nie, X., et al., 2011a. Growth response and toxic effects of three antibiotics on Selenastrum capricornutum evaluated by photosynthesis rate and chlorophyll biosynthesis. J. Environ. Sci. 23, 1558-1563.

Liu, B., Nie, X., Liu, W., et al., 2011b. Toxic effects of erythromycin, ciprofloxacin and sulfamethoxazole on photosynthetic apparatus in Selenastrum capricornutum. Ecotoxicol. Environ. Saf. 74, 1027-1035. https://doi.org/10.1016/j.ecoenv.2011.01 022 .

Lodish, H., Berk, A., Kaiser, C.A., et al., 2008. Molecular Cell Biology, 6th ed. W. Freeman and Company, New York.

Machado, M.D., Soares, E.V., 2012a. Development of a short-term assay based on the evaluation of the plasma membrane integrity of the alga Pseudokirchneriella subcapitata. Appl. Microbiol. Biotechnol. 95, 1035-1042. https://doi.org/10.1007/ s00253-012-4185-y.

Machado, M.D., Soares, E.V., 2012b. Assessment of cellular reduced glutathione content in Pseudokirchneriella subcapitata using monochlorobimane. J. Appl. Phycol. 24. https://doi.org/10.1007/s10811-012-9811-7.

Machado, M.D., Soares, E.V., 2013. Optimization of a microplate-based assay to assess esterase activity in the alga Pseudokirchneriella subcapitata. Water Air Soil Pollut. 224, 1358. https://doi.org/10.1007/s11270-012-1358-3.

Machado, M.D., Soares, E.V., 2014. Modification of cell volume and proliferative capacity of Pseudokirchneriella subcapitata cells exposed to metal stress. Aquat. Toxicol. 147, 1-6. https://doi.org/10.1016/j.aquatox.2013.11.017.

Machado, M.D., Soares, E.V., 2016. Short- and long-term exposure to heavy metals in duced oxidative stress response in Pseudokirchneriella subcapitata. Clean - Soil, Air, Water 44, 1578-1583. https://doi.org/10.1002/clen.201600020.

Machado, M.D., Soares, E.V., 2019. Sensitivity of freshwater and marine green algae to three compounds of emerging concern. J. Appl. Phycol. https://doi.org/10.1007/ s10811-018-1511-5.

Martínez, J.L., 2017. Effect of antibiotics on bacterial populations: a multi-hierarchical selection process. F1000Res 6, 51. https://doi.org/10.12688/f1000research.9685.1.

Maul, J.E., Lilly, J.W., Cui, L., et al., 2002. The Chlamydomonas reinhardtii plastid chromosome: islands of genes in a sea of repeats. Plant Cell 14, 2659-2679. https://doi org $/ 10.1105 /$ tpc. 006155 .

McArdell, C.S., Molnar, E., Suter, M.J.F., et al., 2003. Occurrence and fate of macrolide antibiotics in wastewater treatment plants and in the Glatt Valley Watershed, Switzerland. Environ. Sci. Technol. 37, 5479-5486. https://doi.org/10.1021/ es034368i.

Milić, N., Milanović, M., Letić, N.G., et al., 2013. Occurrence of antibiotics as emerging contaminant substances in aquatic environment. Int. J. Environ. Health Res. 23, 296-310. https://doi.org/10.1080/09603123.2012.733934.

Mitosch, K., Bollenbach, T., 2014. Bacterial responses to antibiotics and their combinations. Environ. Microbiol. Rep. 6, 545-557. https://doi.org/10.1111/1758-2229. 12190.

Nie, X.P., Liu, B.Y., Yu, H.J., et al., 2013. Toxic effects of erythromycin, ciprofloxacin and sulfamethoxazole exposure to the antioxidant system in Pseudokirchneriella subcapitata. Environ. Pollut. 172, 23-32. https://doi.org/10.1016/j.envpol.2012.08.013.

OECD, 2011. Test No. 201: Freshwater Alga and Cyanobacteria, growth Inhibition Test, Organization for Economic Co-operation and Development. Paris, France.

Okada, K., Satoh, K., Katoh, S., 1991. Chloramphenicol is an inhibitor of photosynthesis. FEBS Lett. 295, 155-158. https://doi.org/10.1016/0014-5793(91)81407-Y.

Pan, X., Deng, C., Zhang, D., et al., 2008. Toxic effects of amoxicillin on the photosystem II of Synechocystis sp. characterized by a variety of in vivo chlorophyll fluorescence tests. Aquat. Toxicol. 89, 207-213. https://doi.org/10.1016/j.aquatox.2008.06.018.

Pérez, R.A., Albero, B., Férriz, A., et al., 2017. Analysis of macrolide antibiotics in water by magnetic solid-phase extraction and liquid chromatography-tandem mass spectrometry. J. Pharm. Biomed. Anal. 146, 79-85. https://doi.org/10.1016/j.jpba.2017. 08.013.

Reyes-Prieto, A., Weber, A.P.M., Bhattacharya, D., 2007. The origin and establishment of the plastid in algae and plants. Annu. Rev. Genet. 41, 147-168. https://doi.org/10. 1146/annurev.genet.41.110306.130134.

Ritchie, R.J., 2008. Universal chlorophyll equations for estimating chlorophylls a, b, c, and $\mathrm{d}$ and total chlorophylls in natural assemblages of photosynthetic organisms using acetone, methanol, or ethanol solvents. Photosynthetica 46, 115-126. https:// doi.org/10.1007/s11099-008-0019-7.

Rojickova-Padrtova, R., Marsalek, B., 1999. Selection and sensitivity comparisons of algal species for toxicity testing. Chemosphere 38, 3329-3338. https://doi.org/10.1016/ S0045-6535(98)00566-9.

Samson, G., Morisette, J.C., Popovic, R., 2018. Copper quenching of thr variable fluorescence in Dunaliella tertiolecta. New evidence for a copper inhibition effect on PSII photochemistry. Photochem. Photobiol. 48, 329-332. https://doi.org/10.1111/j 1751-1097.1988.tb02829.x.

Schafhauser, B.H., Kristofco, L.A., de Oliveira, C.M.R., et al., 2018. Global review and analysis of erythromycin in the environment: occurrence, bioaccumulation and antibiotic resistance hazards. Environ. Pollut. 238, 440-451. https://doi.org/10.1016/j. envpol.2018.03.052.

Sendra, M., Moreno-Garrido, I., Blasco, J., et al., 2018. Effect of erythromycin and modulating effect of $\mathrm{CeO} 2 \mathrm{NPs}$ on the toxicity exerted by the antibiotic on the microalgae Chlamydomonas reinhardtii and Phaeodactylum tricornutum. Environ. Pollut. 242, 357-366. https://doi.org/10.1016/j.envpol.2018.07.009.

Shi, L.-X., Theg, S.M., 2013. The chloroplast protein import system: from algae to trees. Biochim. Biophys. Acta 1833, 314-331. https://doi.org/10.1016/j.bbamcr.2012.10. 002.

Soll, J., Schleiff, E., 2004. Protein import into chloroplasts. Nat. Rev. Mol. Cell Biol. 5, 198-208. https://doi.org/10.1038/nrm1333.

Soto, P., Gaete, H., Eliana Hidalgo, M., 2011. Assessment of catalase activity, lipid peroxidation, chlorophyll-a, and growth rate in the freshwater green algae Pseudokirchneriella subcapitata exposed to copper and zinc. Lat. Am. J. Aquat. Res. 39, 280-285. https://doi.org/10.3856/vol39-issue2-fulltext-9.

Sousa, C.A., HMVM, Soares, Soares, E.V., 2018. Toxic effects of nickel oxide (NiO) nanoparticles on the freshwater alga Pseudokirchneriella subcapitata. Aquat. Toxicol. 204, 80-90. https://doi.org/10.1016/j.aquatox.2018.08.022.

Sun, J., Liu, D., 2003. Geometric models for calculating cell biovolume and surface area for phytoplankton. J. Plankton Res. 25, 1331-1346. https://doi.org/10.1093/plankt/ fbg096.

Tarpey, M.M., Wink, D.A., Grisham, M.B., 2004. Methods for detection of reactive metabolites of oxygen and nitrogen: in vitro and in vivo considerations. Am. J. Physiol. Regul. Integr. Comp. Physiol. 286, R431-44. https://doi.org/10.1152/ajpregu. 00361.2003 .

US-EPA, 2012. Algal Toxicity (OCSPP 850.4500). Ecological Effects Test Guidelines. Pollution Prevention. United States Environmental Protection Agency. EPA 712-C006. Washington, DC.

Valavanidis, A., Vlahogianni, T., Dassenakis, M., et al., 2006. Molecular biomarkers of oxidative stress in aquatic organisms in relation to toxic environmental pollutants. Ecotoxicol. Environ. Saf. 64, 178-189. https://doi.org/10.1016/j.ecoenv.2005.03. 013.

Välitalo, P., Kruglova, A., Mikola, A., et al., 2017. Toxicological impacts of antibiotics on aquatic micro-organisms: a mini-review. Int. J. Hyg. Environ. Health 220, 558-569. https://doi.org/10.1016/j.ijheh.2017.02.003.

Waiser, M.J., Swerhone, G.D.W., Roy, J., et al., 2016. Effects of erythromycin, trimethoprim and clindamycin on attached microbial communities from an effluent dominated prairie stream. Ecotoxicol. Environ. Saf. 132, 31-39. https://doi.org/10. 1016/j.ecoenv.2016.05.026.

Wan, J., Guo, P., Peng, X., et al., 2015. Effect of erythromycin exposure on the growth, antioxidant system and photosynthesis of Microcystis flos-aquae. J. Hazard. Mater. 283, 778-786. https://doi.org/10.1016/j.jhazmat.2014.10.026.

Xue, B., Zhang, R., Wang, Y., et al., 2013. Antibiotic contamination in a typical developing city in south China: occurrence and ecological risks in the Yongjiang River impacted by tributary discharge and anthropogenic activities. Ecotoxicol. Environ. Saf. 92, 229-236. https://doi.org/10.1016/j.ecoenv.2013.02.009.

Yruela, I., Alfonso, M., Ortiz de Zarate, I., et al., 1993. Precise location of the Cu(II)inhibitory binding site in higher plant and bacterial photosynthetic reaction centers as probed by light-induced absorption changes. J. Biol. Chem. 268, 1684-1689.

Zhang, R., Tang, J., Li, J., et al., 2013. Occurrence and risks of antibiotics in the coastal aquatic environment of the Yellow Sea, North China. Sci. Total Environ. 450-451, 197-204. https://doi.org/10.1016/j.scitotenv.2013.02.024.

Zuccato, E., Castiglioni, S., Fanelli, R., 2005. Identification of the pharmaceuticals for human use contaminating the Italian aquatic environment. J. Hazard. Mater. 122, 205-209. https://doi.org/10.1016/j.jhazmat.2005.03.001. 